\title{
minutes of the meeting of the AMS Council
}

\section{8-29 September 1995, Boston, Massachusetts}

\begin{abstract}
The Council convened at 8:53 A.M., 28 September.
Present: President Houghton; President-Elect Try; Past Presidents Washington and Ryan; Councilors LeMone, Rasmusson, Sorooshian, Carter, Greenfield, Hales, Pauley, Kalnay, Randall, Sanford, and Somerville; Commissioners Carnahan, Simpson, Snow, Orville, and Braham; Executive Director Hallgren; Recorder Baum
\end{abstract}

\section{Mail ballots}

Executive Director Hallgren announced that mail ballots since the last meeting had resulted in approval of (1) the minutes of the two Council meetings on 15 January, (2) the formation of the Central Arkansas and Kentucky-Southern Indiana Chapters, (3) the election to Member status of those individuals recommended by the Admissions Committee at its meetings of 9 March and 8 June, (4) the nominations for the 199596 AMS Minority Scholarships, and (5) the appointment of these new editors: JAM: Mike Garstang; JAS: Gerald North (1 year); JCLIM: David A. Randall; and Earth Interactions: Eric Barron.

\section{Revised frames of reference for STAC committees}

Commissioner Orville received some comments on revised frames of reference for several STAC committees, which had been submitted to the Council for information.

\section{Appointment of STAC commissioner}

Commissioner Orville, having served more than six years, wishes to be relieved as of the end of the next Annual Meeting. On the recommendation of the Executive Committee, the Council voted to appoint Richard D. Rosen as commissioner for a term ending in 1999.

(C)1996 American Meteorological Society

\section{Proposed funding of STAC conferences}

The Council was informed that Commissioner Orville had transmitted a proposal that the allocation of $\$ 1500$ be authorized for every conference organized by a standing committee. The Executive Committee views with favor supporting only the travel (no honoraria) of invited speakers and students, with any funds to be disbursed only by headquarters (not meeting chairs) and to be available for all AMS-sponsored scientific meetings. The Executive Director has been asked to develop a detailed plan on this matter for consideration by the Executive Committee and the Council in January.

Secretary-Treasurer Spengler joined the meeting during discussion of the next item.

\section{Statement on ozone}

Council members had several suggestions for Councilor Hales for improvement of a statement on ozone, which was generally well received. A modified version will be forthcoming.

\section{Statement on satellites}

A proposed statement on satellites was reviewed; there was clear feeling that new issues had arisen since the statement was undertaken and that there was need for more focus. The Council asked a subgroup consisting of President-Elect Try (chair), Councilors Kalnay and Somerville, and Commissioner Orville to interact with the chair of the Committee on Satellite Meteorology and Oceanography on the matter. 


\section{Memorializing of Verner E. Suomi}

A variety of alternatives for memorializing Past President and Honorary Member Verner E. Suomi was considered. In accord with the feeling of the Executive Committee, the Council approved the concept of an award, a technology counterpart to the Charney scientific award. The recorder was asked to prepare proposed detailed wording for consideration in January.

\section{Appointment of editors}

On the recommendation of Commissioner Simpson and the Executive Committee, the Council approved the following appointments or reappointments of editors for the 1996-1999 period: JAS: William Cotton, co-chief editor; Roger Pielke, co-chief editor; Anne R. Douglass, editor; Ngar-Cheung Lau, editor; Joseph Tribbia, editor; JCLIM: Inez Fung, editor; JPO: Eli Katz, chief editor (to 1997 only); Greg Holloway, editor; JAM: Harshvardan, editor; $M W R$ : Peter Ray, chief editor; WAF: Bradley Colman, chief editor; J. Michael Fritsch, editor; John Monteverdi, editor; JTECH: Dusan Zrnić, co-chief editor.

\section{Appointment of Publications Commission member}

On the recommendation of Commissioner Simpson and the Executive Committee, the Council voted to appoint Marvin Geller as a member-at-large of the Publications Commission for the 1996-1999 period.

\section{Editors' Awards}

On the recommendation of Commissioner Simpson and the Executive Committee, the Council approved the following Editors' Awards: MWR: Richard Orville; JTECH: Dudley Chelton; JAS: Quin Xu; JCLIM: Dennis Hartmann; JAM: Jeremy Hales; WAF: Paul J. Dallavalle; and JPO: Ed Sarachik.

\section{Copyright policy}

Associate Executive Director Keith Seitter reviewed for the Council a proposed new copyright policy, considered by the Information Systems Committee, the Publications Commission, and a copyright lawyer. It includes explicit guidelines for what can and cannot be done in posting electronic versions of articles on the Internet. The policy, subject to minor modifications, was approved after extended discussion and will be published in the Bulletin and on the World Wide Web.

\section{Electronic publishing}

Keith Seitter briefed the Council, for information, on the spectrum of electronic publishing activities within the Society. The central element is the new electronic journal, Earth Interactions, which is being used as a vehicle to gain capabilities in a wide array of electronic publishing techniques. Various aspect of the topic were explored in discussion.

\section{CCM statement on continuing professional development}

Commissioner Carnahan and the Board of Certified Consulting Meteorologists have recommended adoption of guidelines for continuing professional development of CCMs, to be added to the CCM program description published in the Bulletin. The Council approved the statement, which will first appear in August 1996.

\section{Board on Private Sector Meteorology}

A modified mission statement for the Board on Private Sector Meteorology, as recommended by the Board and Commissioner Carnahan, was approved by the Council.

\section{Appointments to boards of Commission on Professional Affairs}

On the recommendation of Commissioner Carnahan and the Executive Committee, the Council approved the following appointments: Board of Certified Consulting Meteorologists: Paul M. Fransioli to serve as 1996 chair and Lee E. Branscome to serve a term expiring in 2000; Board of Broadcast Meteorol- 
ogy: Michael J. Madson to serve as 1996 chair and Heidi Sonnon and Tim Brian McGill to serve terms expiring in 1999; Board of Private Sector Meteorology: Stanley L. Marsh, Jr.to serve as 1996 chair and Virginia Bigler-Engler and Phillip D. Falconer to serve terms expiring in 1999; Board for Operational Government Meteorologists: John S. Livingston to serve as 1996 chair and Michael Davenport and Jeff Waldstreicher to serve terms expiring in 1999.

\section{Board for Continuing Education}

The Council received the final report of the ad hoc Committee on Continuing Education and voted to establish a Board for Continuing Education within the Commission on Professional Affairs. The new board is to consist of the chair of the Board on Meteorological and Oceanographic Education in Universities, serving ex-officio, and six members serving three-year terms, to be nominated to the Council by the Professional Affairs commissioner in consultation with the STAC commissioner and the Education and Human Resources commissioner.

\section{Appointments to Board for Continuing Education}

On the recommendation of Commissioner Carnahan, the Council approved the following initial appointments to the Board for Continuing Education: John W. Wilson (chair for 1996) and Allan C. Eustis, to serve terms expiring in 1999; Troy M. Kimmel, Jr. and Steven B. Newman, to serve terms expiring in 1998; and Ronald E. Rinehart and Timothy C. Spangler to serve terms expiring in 1997.

\section{Private sector survey (Part I)}

President Houghton, in anticipation of luncheon discussions, reviewed some initial results of his survey of private sector meteorology. It is clear that this sector is rapidly becoming most important in the employment of meteorologists and has great interest in individuals with the bachelor's degree.

The Council recessed from 12:05 P.M. to 12:55 P.M.

\section{Private sector survey (Part II)}

There was some further discussion on this subject. Survey results will be published in the Bulletin.

\section{Honorary Members}

With the Secretary-Treasurer temporarily out of the room, the Council accepted the Executive Committee's recommendation that Joachim P. Kuettner and Kenneth C. Spengler be elected to the grade of Honorary Member.

\section{Appointments to groups under Education and Human Resources Commission}

On the recommendation of Commissioner Snow and the Executive Committee, the Council approved the following appointments: Committee of Judges for Undergraduate Awards: Gregory P. Byrd to serve as chair for 1996 and Michael I. Biggerstaff to serve a term expiring in 2000; Board of Women and Minorities: J. Marshall Shepherd to serve as chair for 1996, and the following to serve terms expiring in 1999: Sim Aberson, John Cortinas, Jr., Esther McKay, and Mishelle Michaels; Board of School and Popular Meteorological and Oceanographic Education: Renee A. McPherson, Barry A. Richwien, Patricia A. Phoebus, Henry W. Robinson, and Marianne Ceritelli to serve terms expiring in 1999; Board of Meteorological and Oceanographic Education in Universities: Lisa M. Bastiaans, Ben Watkins, Paul Croft, and Leonard J. Pietrafesa to serve terms expiring in 1999.

\section{Local chapter study}

Commissioner Snow reviewed an interim report by the ad hoc Committee on Local Chapters, whose final report should be forthcoming in January. The Council took three actions as a result of the report and discussion: (1) publication of the Local Chapter Officers Handbook was approved; (2) creation of a Committee on Local Chapter Affairs as a committee of the Executive Committee was approved; and (3) the editor of the Bulletin was asked to consider a column in the publication dealing with local chapter affairs; this column would feature news and commentary from the 
Headquarters of interest to local chapters, and tips and insights on effective chapter operations.

\section{Committee on Societal Impacts}

Commissioner Braham accepted the proposed modifications of the Planning Commission report considered by the Executive Committee in July. Thus, the Council voted to establish a Committee on Societal Impacts, to operate as a committee of the Executive Committee for no more than three years. During that time, the Committee is asked to review and make suggestions on the proposed (by the Planning Commission) frame of reference, to recommend whether the Committee should be considered as permanent and, if so, where it should be placed in the Society's structure. The interim function of the Committee is to interact with other AMS committees and other societies in matters involving environmental policy, impact assessment, and response, and to encourage and support, as appropriate, sessions focusing on these issues in the Society's topical meetings. There was some discussion of potential composition of the Committee, and President Houghton solicits written suggestions.

\section{Ad hoc Committee on Membership Diversification}

The Planning Commission, having explored the relatively stagnant membership, and having found that there are not many oceanographers and hydrologists as well as large nonrenewal rates after one or two years of membership, has recommended establishment of an ad hoc committee to pursue the first of these problems. The Council voted to appoint an ad hoc Committee on Membership Diversification, consisting of Councilor Eugene M. Rasmusson (chair), Councilor Thomas B. Sanford, Councilor Soroosh Sorooshian, Dara Entekhabi, and Roger B. Lukas. To deal with the second problem, the Council asked Executive Director Hallgren to arrange for further studies of new member drop-out for the purposes of understanding the reasons for it and to recommend remedial measures.

\section{Appointments to Planning Commission}

On the recommendation of the Executive Committee, the Council voted to appoint Past President Charles L. Hosler as Planning Commissioner for the period 1996-1999, and to appoint H. Thomas Rossby a member of the Commission for a term ending in 2000 .

\section{Awards Committee approvals}

On the recommendation of the Awards Committee and the Executive Committee, the Council voted to confer the following awards: Rossby: David Atlas; Charney: Yoshio Kurihara; Brooks: Eli Joel Katz; Cleveland Abbe: Ronald C. Taylor; Meisinger: J. David Neelin; Houghton: David Fahey; Battan: Thomas E. Graedel and Paul J. Crutzen; Corporation: Cray Research, Inc.; Special Awards (2): Roger Lukas and Peter Webster, and John Christy and Roy W. Spencer.

\section{Awards recommended by various other committees}

On the recommendations of the appropriate responsible committee and the Executive Committee, the Council voted to confer the following awards: Outstanding Contribution to the Advance of Applied Meteorology: Hal Brown; Outstanding Service by a Broadcast Meteorologist: Len Slesick; Mitchell: Col. Gene J. Pfeffer, USAF; Reichelderfer: Max Mayfield (Britt Max); Exceptional Specific Prediction: Andrew Stern and Jim Wiesmueller; Biometeorology: Michael E. Irwin; Leviton: Scott J. Richardson.

\section{Undergraduate awards}

In accord with recommendations of the Committee of Judges for Undergraduate Awards, the Council approved the following five individuals (in ranked order) for the undergraduate scholarships: Cristina Kaufman, Jeffrey Zogg, Joseph MacDonald, Jeffrey Brandberg, and Michael Whitney. Further, it approved the following two individuals (in ranked order) for the Father James B. Macelwane Award: Daniel P. Guertin and Timothy M. Winter. 


\section{Sverdrup Gold Medal}

President Houghton announced that he had accepted the recommendation of the Sverdrup Gold Medal Committee that the award be conferred on Julian P. McCreary.

\section{Sverdrup Gold Medal}

Committee President Houghton announced his appointment of Jim Price to the Sverdrup Gold Medal Committee for a term to expire in 1999.

\section{3i. Henry Stommel Research Award}

On the recommendation of the Henry Stommel Research Award Committee and the Executive Committee, the Council voted to confer the Stommel Award on Joseph L. Reid.

\section{Stommel Award Committee}

On the recommendation of President Houghton, the Council voted to extend the term of Dennis Moore on this committee to 1999.

\section{Call for action}

After some discussion of the current turbulence on the Washington scene, the Council voted to accept a recommendation from the Executive Committee that it authorize two undertakings: (1) The executive director should initiate exploration with the president of the University Corporation for Atmospheric Research of preparation of a 1996 "issues paper" comparable to the joint documents prepared in 1988 and 1992, and (2) issuance by the Committee on Public Policy of a statement addressing shorter-term budget and organizational matters.

The Council recessed at 5:02 P.M. and reconvened at 8:29 A.M. the following morning, 29 September.

Present: Identical with the preceding day (above), except that Councilor Hooke was also in attendance and Secretary-Treasurer Spengler was present from the beginning.

\section{Meetings abroad}

President Houghton reminded the Council that, due to many criticisms about the frequency of meetings abroad, the Executive Committee had decided that any such meeting to be scheduled henceforth will require advance approval by the Executive Committee, based on justification.

\section{Forthcoming meetings}

President Houghton announced that arrangements for the 1996 Annual Meeting (Atlanta) are essentially complete. Programs will appear in the October 1995 Bulletin and the meeting will be a very large one. President-Elect Try indicated that the 1997 Annual Meeting (Long Beach) will emphasize interdisciplinary aspects of our science with a special focus on hydrology. This will be our first meeting at a convention center. The 1998 Annual Meeting has been set for Phoenix.

\section{Budget}

Executive Director Hallgren briefed the Council in detail on the revised 1995 and the proposed 1996 budgets. There was extensive discussion of the budget itself and of the possible publication of the briefing or other information besides the auditor's report. Finally, it was voted to ask the executive director to draft an overview giving the general flavor of the financial philosophy, status, and outlook of the Society for signature by the entire Council and for publication. The budget for 1996 was approved.

\section{Scholarship/Fellowship program}

The executive director briefed the Council on the status of scholarship and fellowship support for 199697. Corporate "downsizing" is beginning to put a squeeze on funding for this sort of activity, though there is no serious problem yet.

\section{Program in Support of Science and Education}

Executive Director Hallgren reviewed documentation on the Program in Support of Science and Edu- 
cation, the follow-on to the 75th Anniversary Campaign, which Past President Ryan has agreed to chair. Comments and suggestions were offered.

\section{Election of Fellows}

On the recommendation of the Committee on Fellows and the Executive Committee, the Council voted to elect the following to the grade of Fellow:

$\begin{array}{ll}\text { Barron, Eric J. } & \text { Plante, Robert J. } \\ \text { Beard, Kenneth V. } & \text { Raman, Sethu } \\ \text { Chen, Tsing-Chang } & \text { Schoeberl, Mark R. } \\ \text { Cho, Han-Ru } & \text { Shapiro, Lloyd J. } \\ \text { Curry, Judith A. } & \text { Sherr, Paul E. } \\ \text { Golden, Joseph } & \text { Shuttleworth, James W. } \\ \text { Hallett, John } & \text { Smith, David R. } \\ \text { Hardesty, Robert M. } & \text { Swanson, Robert N. } \\ \text { Hardy, Kenneth R. } & \text { Thompson, Anne M. } \\ \text { Junker, Norman W. } & \text { Wakimoto, Roger } \\ \text { Katz, Eli J. } & \text { Zillman, John W. } \\ \text { Knight, Charles A. } & \end{array}$

\section{Committee on Fellows}

On the recommendation of the Executive Committee, the Council approved the following Committee on Fellows for 1996: Warren M. Washington (chair), Thomas H. VonderHaar, Kristina B. Katsaros, Rafael L. Bras, Joseph M. Pelissier, and George E. McVehil.

\section{Awards Committee}

The Council was informed that the Executive Committee had appointed the following Awards Committee for 1996: James R. Holton (chair), Steven R. Hanna, William B. Rossow, Louis W. Uccellini, and Judith A. Curry.

\section{Nominating Committee}

The Council was informed that the Executive Committee had appointed the following Nominating Committee for 1996: William D. Bonner (chair), George L. Frederick, Jr., Peter J. Webster, Robert A. Schiffer, Dennis L. Hartmann, and Kenneth C. Crawford.

\section{Fifth councilor}

On the recommendation of the Executive Committee, the Council voted for Wilfried Brutsaert as the fifth councilor for the 1996-1999 term.

\section{Reduced dues for high-school students}

At the request of the executive director, the Council voted to allow student privileges (half-price dues) to be extended to precollege students as Associate Members.

\section{Increased dues for Corporation and Institutional Members}

On the recommendation of the executive director, the Council voted to increase from $\$ 300$ to $\$ 400$ the basic level dues for Corporation and Institutional Members.

\section{Society name change}

Since the January 1995 meeting of the Council, where it was raised by Past President Don Johnson, there has been sporadic discussion of changing the name of the Society to the American Meteorological and Oceanographic Society. Discussion was resumed, showing a wide range of opinions as to the wisdom of any action. The ad hoc Committee on Membership Diversification (see item 24, above) was asked to consider the various points raised in the discussion.

\section{Election of new members}

The Council voted to elect to the grade of Member those individuals recommended by the Admissions Committee at its meeting of 21 September 1995.

The Council recessed from 12:30 P.M. to 1:09 P.M.

\section{Affiliations with other organizations}

The executive director reviewed a listing of the Society's affiliations with other organizations, received comments, and answered questions. No action was needed. 


\section{Status reports}

Executive Director Hallgren, members of the staff, and members of the Council gave brief status reports on the journals, and the Bulletin, MGA, books, the $\mathrm{K}-12$ educational initiatives, the Glossary, international data exchange, WITI/COMET, the ad hoc committee on the ITS, and the AMS Internet node. The Council expressed its desire to consider at the next meeting a statement of appreciation to all those who contributed to the "victory" on the international data exchange matter; President Houghton will assign the drafting of such a statement.

\section{Committee on the History of Atmospheric Science}

President Houghton announced that the Executive Committee had appointed William Barney, Charles Hosler, George Platzman, and Mel Shapiro to this committee for the 1996-1999 period.

\section{Committee on Interactive Information and Processing Systems}

President Houghton announced that the Executive Committee had reappointed Bob Brammer as chairman of this committee for 1996 and appointed Robert Landis and reappointed Horst Bottger, Patricia Pauley, and Jim Schiavone as members for the 19961999 period.

\section{COMPUP assignment}

See item 33, above. The assignment given the Committee on Public Policy was further discussed, the earlier action of the American Association for the Advancement of Science (to which we were party) was reviewed, and various suggestions were made for consideration by COMPUP.

\section{Next meeting}

The next meeting of the Council will be in Atlanta on Sunday, 28 January 1996.

The Council adjourned at 2:42 P.M.

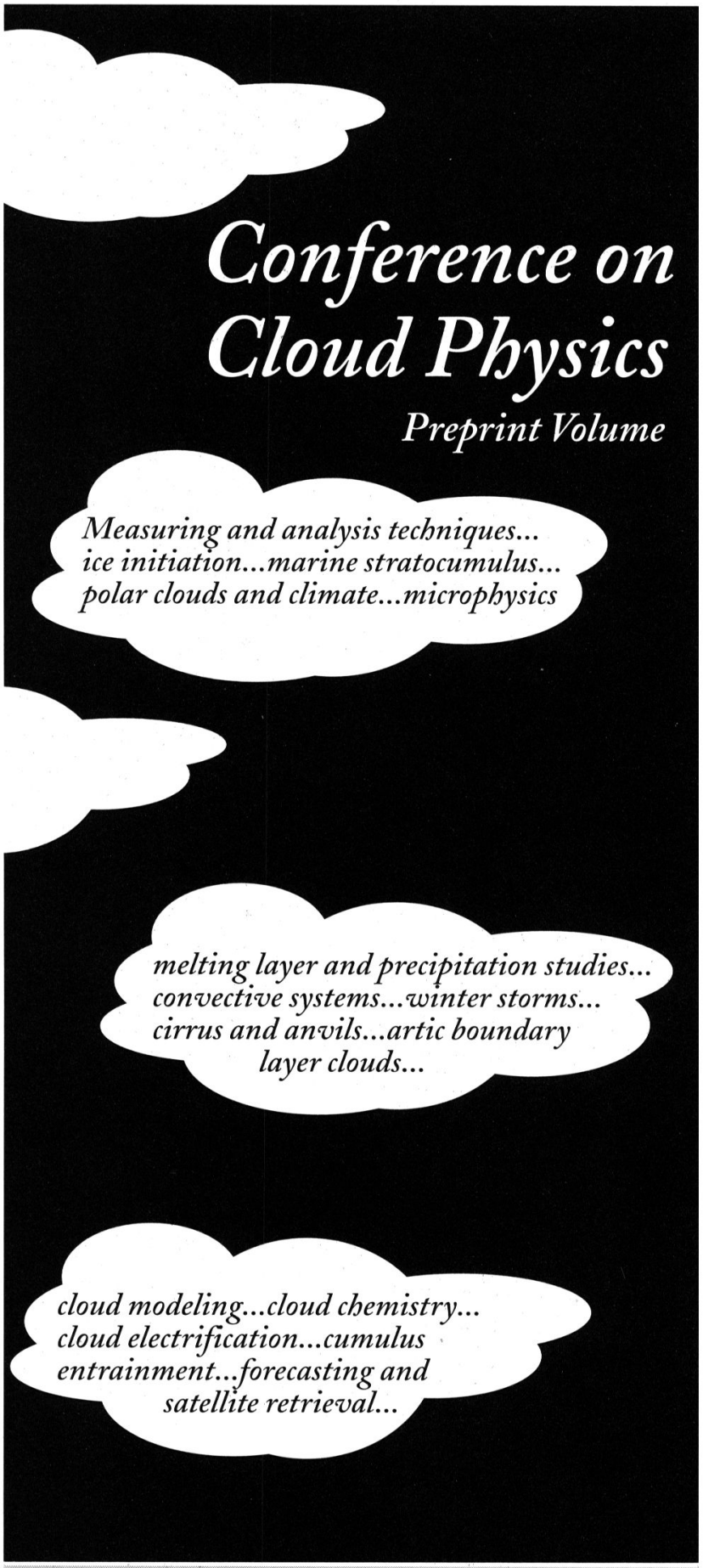

$$
\text { Dallas, Texas }
$$

$$
15-20 \text { January } 1995
$$

Softbound, BAW, $630+$ pp., $\$ 50 /$ list, $\$ 35 /$ members. Send prepaid orders to Order Department, AMS, 45 Beacon Street, Boston, MA 02108-3693.

American Meteorological Society 


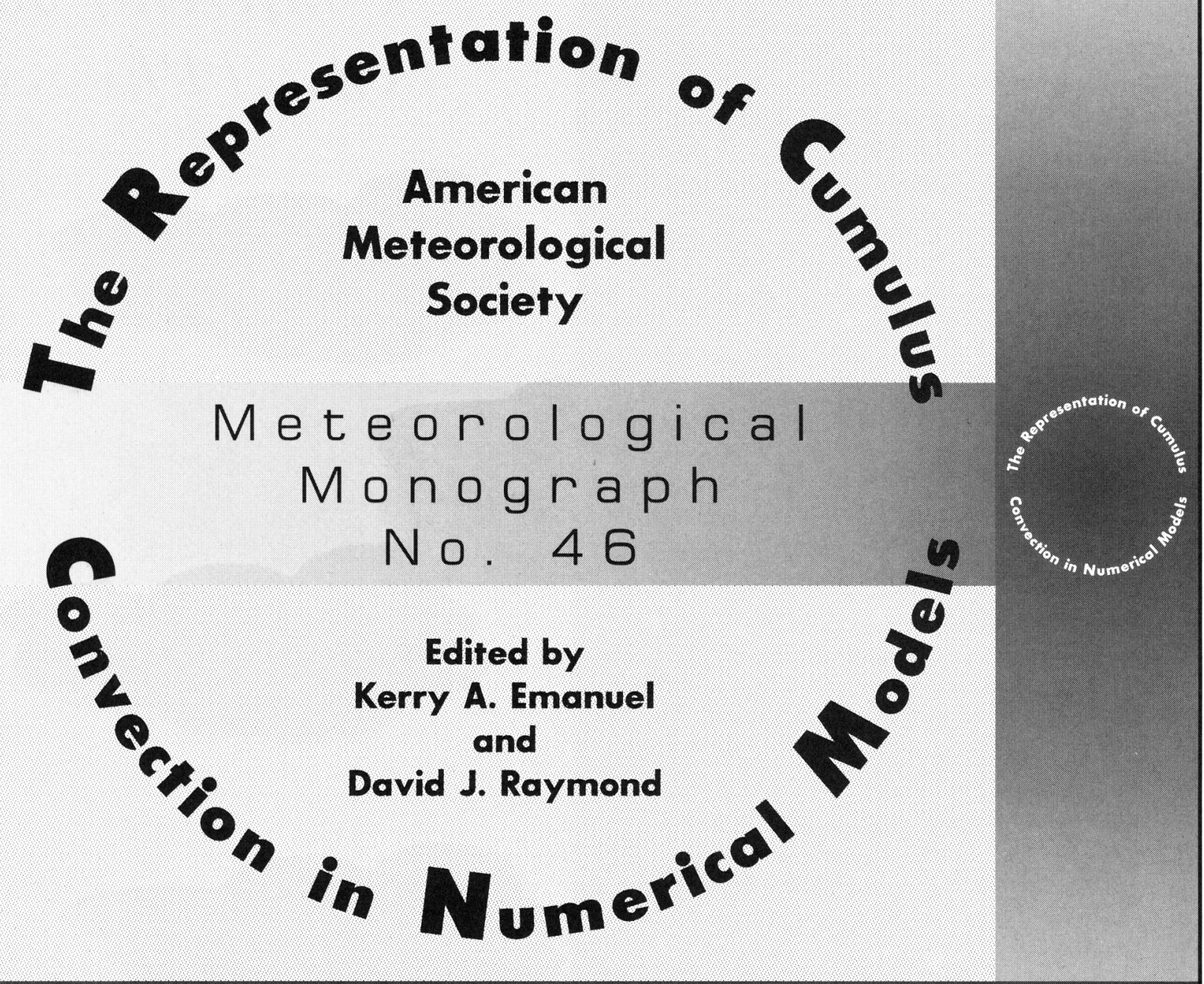

Cumulus convection is perhaps the most complex and perplexing subgrid-scale process that must be represented in numerical models of the atmosphere. It has been recognized that the water vapor content of large parts of the atmosphere is strongly controlled by cloud microphysical processes, yet scant attention has been paid to this problem in formulating most existing convection schemes. This monograph is the fruit of the labors of many of the leading specialists in convection and convective parameterization to discuss this and other issues. Its topics include: an overview of the problem; a review of "classical" convection schemes in widespread use; the special problems associated with the representation of convection in mesoscale and climate models; the parameterization of slantwise convection; and some recent efforts to use explicit numerical simulations of ensembles of convective clouds to test cumulus representations.

1994 American Meteorological Society. Hardbound, B\&W, 246 pp., \$65 list \$ 45 members (includes shipping and handling). Please send prepaid orders to: Order Department, American Meteorological Society, 45 Beacon St., Boston, MA 02108-3693. 